\title{
Regarding Artists Regarding Labor
}

\author{
ANA TOROK \\ Curatorial Assistant, Department of Drawings and Prints, Museum of Modern Art
}

\begin{abstract}
In the wake of the Occupy movement and broader discussions concerning the state of the global working class, a number of contemporary artists have demonstrated a renewed interest in exploring the politics of labor through the form, content, and distribution of their work. The case studies taken up here reveal and interrogate forms of human labor embedded within or affected by digital technology. By featuring the artists engaged in transactional relationships or performing the role of capitalist, these predominantly video-based artworks act as concrete reflections of a capitalist economic system. Foregrounding the system's problematics through reenactment, these artworks tacitly implicate their creator as well as their viewer within a complex web of social relations. This article examines the shape and significance of artistic labor across these case studies and asks whether the very allowance for this form of recent cultural production might itself hold emancipatory potential.
\end{abstract}

\section{INTRODUCTION}

The Great Recession that began in 2007 and the Occupy movement mounted in response four years later effectively revealed and interrogated capitalism's inherent flaws and systemic injustices. Centered on the physical occupation of New York City's Zucotti Park in 2011, Occupy catalyzed discussion around income inequality, stagnant wages, precarity, indebtedness, and other challenges to the American working class. While the park was eventually cleared and the movement deemed a failure by some, its rhetoric-particularly the memorable numerical distinction between the inordinate wealth of the $1 \%$ and the collective power of the remaining 99\% - continues to tinge the American cultural and political dialogue. The system, once named (or, better yet, shouted down), became subject to increased scrutiny.

Among those analyzing the current state of affairs were a number of contemporary artistsincluding Eva and Franco Mattes, Andrew Norman Wilson, and Josh Kline-who, in works produced between 2009 and 2016, revealed and analyzed various forms of labor implicated in the development of digital technology. While their work spans various methods and approaches, 
these artists' predominantly video-based projects share an attempt to engage in transactional relationships with the laboring subject by performing the role of capitalist, whether literally or conceptually. Their respective artistic strategies, fueled by in-depth research and interviews, stem from developments in artistic practice since the 1960s and, as I argue later in this article, are uniquely situated to explore ethical complexities in a nuanced and unresolved manner, which forces the viewer to recognize the artist's - and, by extension, their own - complicity within an economic system characterized by alienation and exploitation.

\section{ARTISTS REGARDING LABOR}

The case studies discussed in this article derive their impact from rendering visible certain forms of labor that are typically obscured or taken for granted. By reenacting everyday social relations under capitalism, these artworks concretize the inconsistencies, injustices, and wide implications of this system. To better understand this strategy, it is worth considering the important precedent of revelatory criticism inaugurated in Marx's analysis of the commodity. In Capital, Karl Marx's multi-volume critical analysis of capitalism, one follows the commodity as it is produced, bought, and sold. Over the course of his inquiry, Marx peels away layers of abstraction to demonstrate that the source of surplus value lies in the commodification of labor power, ultimately exposing the system's profit-driven and crisis-bound mechanics. As he explains in his often-quoted section on commodity fetishism,

A commodity appears at first sight an extremely obvious, trivial thing. But its analysis brings about that it is a very strange thing, abounding in metaphysical subtleties and theological niceties. So far as it is a use-value, there is nothing mysterious about it... The table continues to be wood, an ordinary, sensuous thing. But as soon as it emerges as a commodity, it changes into a thing which transcends sensuousness. It not only stands with its feet on the ground, but, in relation to all other commodities, it stands on its head, and evolves out of its wooden brain grotesque ideas. ${ }^{1}$

While in use, an item's value follows straightforwardly from its function. Yet, as soon as that item appears on the market and acquires an exchange value, or a price relative to all other commodities, its valuation becomes less clear. Although the item's exchange value appears intrinsic to the commodity itself, its behavior at market in relation to other commodities takes on an autonomous quality - as a quasi-social relation not between producers, but between products. Marx instead demonstrates that it is in large part (alongside other factors) the human labor that remains congealed in the commodity-form which contributes to its exchange value. As he concludes,

The mysterious character of the commodity-form consists therefore simply in the fact that the commodity reflects the social characteristics of men's own labour as objective characteristics of the products of labour themselves, as the socio-natural properties of these things. Hence it 
also reflects the social relation of the producers to the sum total of labour as a social relation between objects, a relation which exists apart from and outside the producers. ${ }^{2}$

The mystery of the commodity-form lies in its obfuscation of the social relations of producers and the labor that went into its production. Without the recognition of human labor as crucial to exchange value, the circulation of commodities appears as a self-regulating process, while the accumulation of wealth by the capitalist class becomes its inevitable result. By obscuring the fundamental role of workers in value production and the continued maintenance of the capitalist system, abstractions serve to disguise exploitation while ensuring that the economic system appears inevitable and eternal.

The development of digital technology and the Internet has, in certain ways, abstracted these social relations further. Despite the pervasiveness of these technologies, simple cognitive shortcuts abound as users often remain ignorant of the sheer materiality necessary for their glossy ubiquity. Collective fantasies of data floating in infinitely expansive virtual clouds, for example, deflect from the environmentally-taxing reality of server farms. Similarly, processes that appear to users to be seamless or automated discretely rely on the labor of human beings to operate smoothly or at all. As anthropologist Mary L. Gray and computer scientist Siddarth Suri write in their 2019 publication Ghost Work: How to Stop Silicon Valley from Building a New Global Underclass:

Billions of people consume website content, search engine queries, tweets, posts, and mobileapp-enabled services every day. They assume that their purchases are made possible by the magic of technology alone. But, in reality they are being served by an international staff, quietly laboring in the background. These jobs, dominated by freelance and contingent work arrangements rather than full-time or even hourly wage positions, have no established, legal status. $^{3}$

Just as consumers might purchase a commodity, such as Marx's illustrative wooden table, without full knowledge of the labor that went into its production, users who navigate the Internet and employ digital devices are often unaware of the human effort involved on the other side of the screen. While there is much discussion in the media regarding the looming threat of automation posed by artificial intelligence, the authors underscore the persistent presence of the human by explaining what they term "the paradox of automation's last mile":

The great paradox of automation is that the desire to eliminate human labor always generates new tasks for humans. What we call "the last mile" is the gap between what a person can do and what a computer can do.... As more companies aspire to give us AI-enabled "smart" digital assistants to manage our calendars and book our flights, we'll need more and more people to step in when AI falls short of our increasingly exacting and extensive demands. ${ }^{4}$ 
The abstractions veiling the network of capitalist social relations serve the interests of the capitalist class in the same way that the invisibility of human labor serves the interests of the owners of these digital technologies by allowing them to function in cost-effective and extraethical ways. ${ }^{5}$ Much like the efforts of the authors of Ghost Work, the artworks discussed here serve to penetrate the pernicious illusion of immateriality to expose the human labor propping up the slick facade of the digital.

The video series Dark Content (2015) by the Italian-born, Brooklyn-based artist duo, Eva and Franco Mattes, for instance, reveals the psychologically demanding and poorly compensated work of Internet content moderation (Figure 1). The artists first became interested in the topic after realizing that their 2010 video No Fun, in which Franco simulates a suicide by hanging for unsuspecting Chatroulette users, had been removed from YouTube. ${ }^{6}$ Assuming it to be an algorithmic error, the artists began to investigate, ultimately learning of the "nerve-wracking, demanding job of thousands of anonymous human beings: people disguised as algorithms." producing Dark Content, the artists posed as a company looking to hire content moderators and instead conducted anonymous interviews with the respondents. Each one of the series' six "episodes," made available on the Dark Net, features a shape-shifting human-like avatar whose text-to-speech monologue recites segments of the interview transcripts. The choice to make the series available on the Dark Net instead of through the "the shiny and sanitized version of the Internet we are all familiar with," apart from making the videos widely and freely available, was meant to encourage exploration of this typically inaccessible virtual realm. ${ }^{8}$ By hosting the series on a .onion domain, websites which evade censorship and are often repositories for the content removed by moderators, ${ }^{9}$ the artwork's "site" aligns with its subject matter, putting the viewer at risk of encountering the sort of illegal or graphic content to which moderators are routinely subjected. Paradoxically, while anonymizing the identity of each worker through the use of avatars and a computerized voice, the incorporation of naturalistic gestures, such as periodic blinking, maps a human form back onto these workers regularly mistaken for algorithms. 


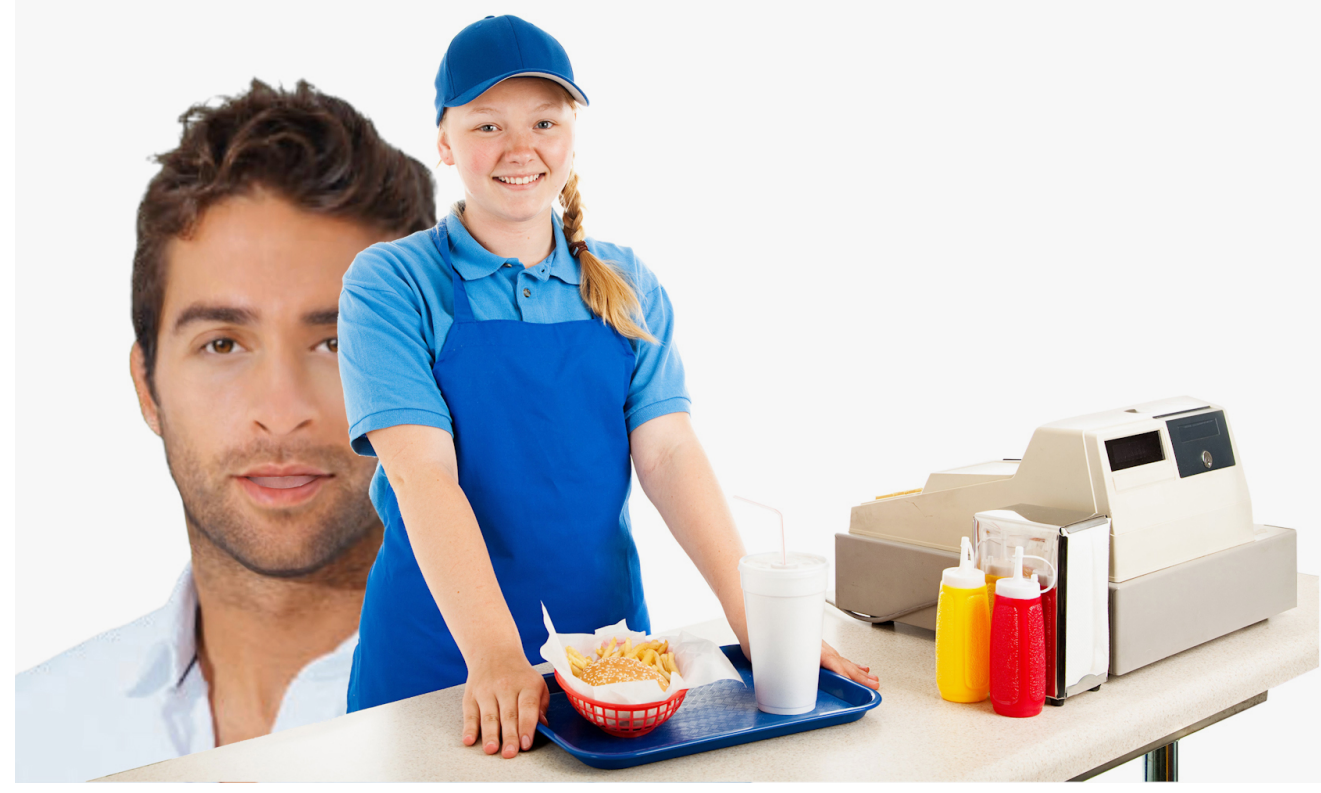

\section{Figure 1. Eva and Franco Mattes, Dark Content, Episode 5: "Something wasn't right," 2015. Screenshot from video. (C) 2019 Eva and Franco Mattes. Courtesy of the artists.}

Their testimonies also help to individualize and literally flesh out their personal experiences. The interviewee featured in episode 4, who was a self-described underachiever in high school and now a content moderator in an office setting, confesses to at least one instance of heavy drinking in response to the disturbing footage they were paid to watch and censor. Vividly recounting their physical reaction to several videos of a man torturing and killing animals, the avatar recalls, "I sat in my gray fucking cubicle and bawled my eyes out for about 10 minutes.... Yes, I can remove the content, but that shit is still in my head." ${ }^{10}$ In justifying the need to compartmentalize disturbing content, they plainly admit, "money is money." Over the course of the episode series, however, its depiction of content moderation-from the workers' anonymity and agency to their labor conditions - is complicated. While several of the interviewees admit to not sharing what they do with friends and family, their motivations vary from a sense of shame to having "mixed feelings about the power." 11 As the subject of episode 1 claims, "I feel a bit like a superhero when I think about how I might be helping a child from seeing a graphic photo," while also acknowledging the frustration of not knowing whether the authorities will intervene when videos showing illegal content, such as child pornography, are flagged. Anonymity is therefore encouraged all around, from the workers as well as from the companies, which abstract workers' identities by anonymizing personal data and which often employ pseudonyms themselves. ${ }^{12}$ Additionally, while often framed as economic precarity, some of the interviewees clearly value the flexibility of being able to work remotely and according to their own schedule. One subject claims to be living in their car as they travel the United States indefinitely, while admitting that the task-based nature of the work means that the budget can suddenly become tight. By watching 
these videos, either on the Dark Net or in a gallery setting installed on upturned office furniture (Figure 2), viewers are presented with a nuanced and subjective account of a relatively novel form of labor that might otherwise, in the service of seamlessness, be glossed over.

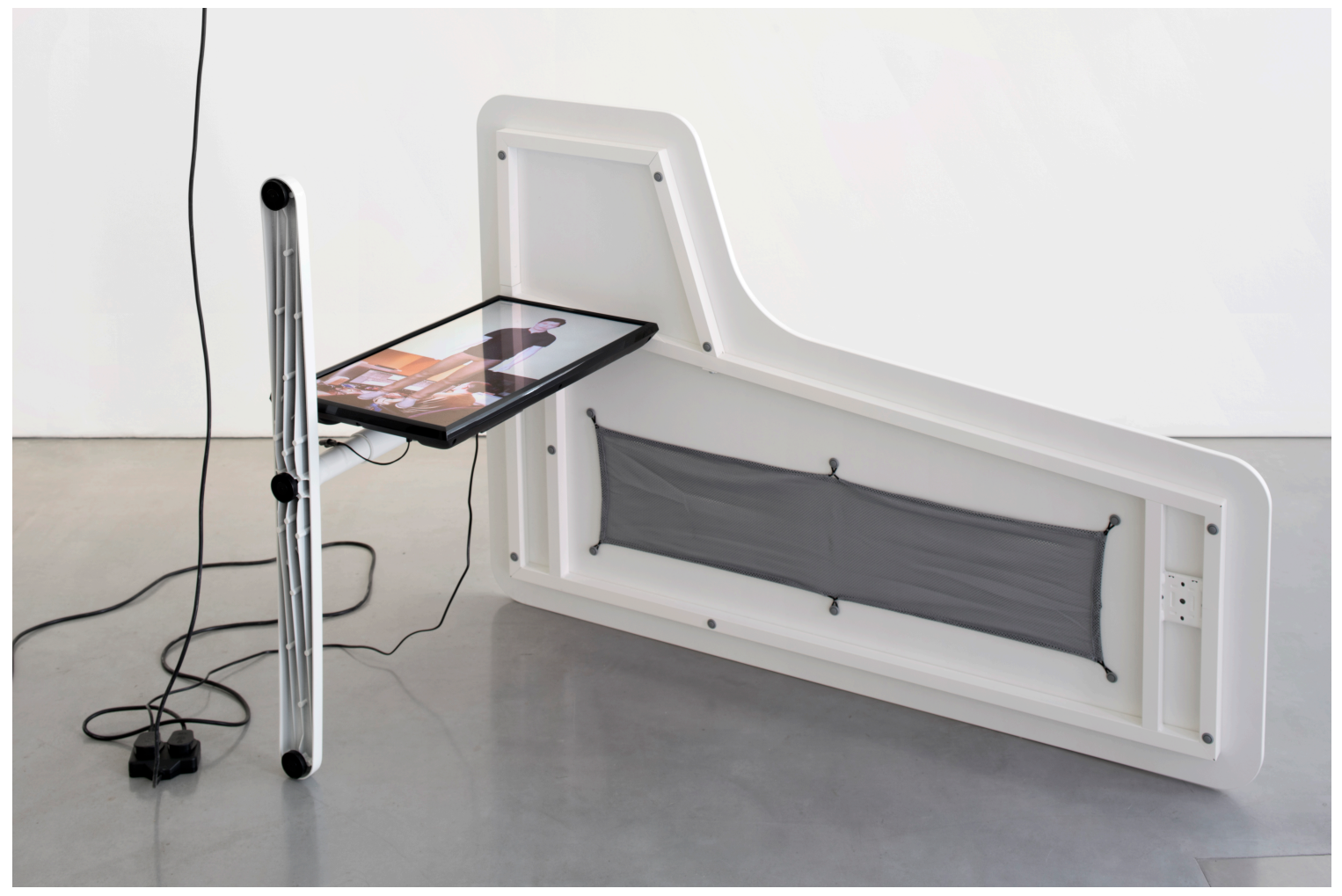

Figure 2. Installation view, Eva and Franco Mattes, Abuse Standards Violations, Carroll/Fletcher Gallery, London, June 10-August 27, 2016. (C) 2019 Eva and Franco Mattes. Courtesy of the artists.

A second series of videos by Eva and Franco Mattes also explores task-based virtual work, although the labor being performed in this case is not as easily categorized. For BEFNOED (2014-), or By Everyone, For No One, Every Day, the artists used crowdsourcing services to hire anonymous workers for "webcam performances." ${ }^{13}$ The instructions provided to the workers required them to perform absurd actions - sit on the ground while completely covered by a blanket, lie face-up across two chairs, or hold a fish between their lips (Figure 3). According to the artists' website, "the resulting videos [we]re then dispersed on obscure, peripheral or forgotten social networks around the world, in Cambodia, Russia, China, South Africa...." Functioning as an engineered and commodified version of viral video stunts, such as "planking" or the "Ice Bucket Challenge," here the actions are destined for remote corners of the Internet, reinforcing its potential as a "many-to-none medium." $B E F N O E D$ becomes a distributed form of artistic collaboration in which the anonymous workers are hired as unwitting virtual participants in a global performance. Whatever the artists' motivations, the resulting videos, 
posted without explanation, undoubtedly add to the glut of strange and unsettling videos which flood the Internet.

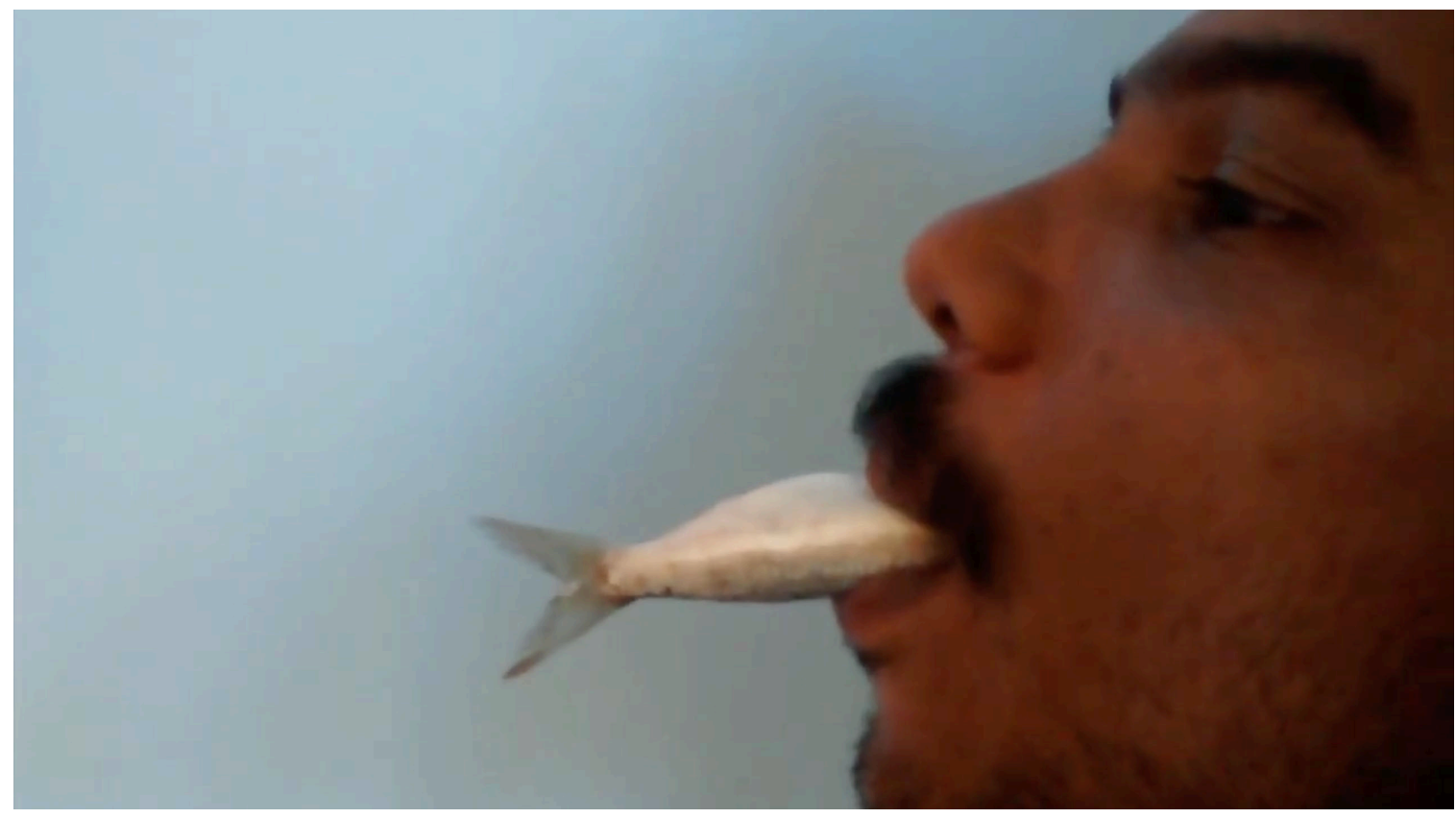

\section{Figure 3. Eva and Franco Mattes, BEFNOED, 2014-. Screenshot from video. (C) 2019 Eva and Franco Mattes. Courtesy of the artists.}

Several works by Los Angeles-based artist Andrew Norman Wilson similarly function as investigations into twenty-first century forms of labor. His video, Workers Leaving the

Googleplex (2011), reveals the existence of an overlooked underclass at the tech company (Figure 4). Wilson became aware of Google's "yellow-badge" workers - who are confined to one area of the corporate campus and excluded from the many worker benefits - while employed there as a subcontracted videographer. ${ }^{15}$ While at the company, he noticed that the workers in an adjacent building exited en masse, daily, at precisely $2: 15 \mathrm{pm}$. This synchronized departure was, as is clear from the video, in marked contrast to the unrestricted movement of other Google workers across the sprawling Mountain View campus. A voiceover by the artist recounts the specifics of his employment at the company, his curiosity regarding the workers whom he later learned were known as ScanOps - those responsible for scanning publications for the Google Books Projectas well as his swift termination. While the official cause of his firing was the unauthorized use of company equipment during work hours, it seems to have been his engagement with the ScanOps workers in order to "develop a relationship with the film's subjects and welcome their perspective into the video" 16 that made the artist an immediate threat. In fact, the company learned of Wilson's project after one of the workers he approached followed the instructions on her badge and alerted management in response to his questioning. Google's prompt response to the video project and its perceived threat is a testament to the strategic effectiveness of increased visibility. $^{17}$ 

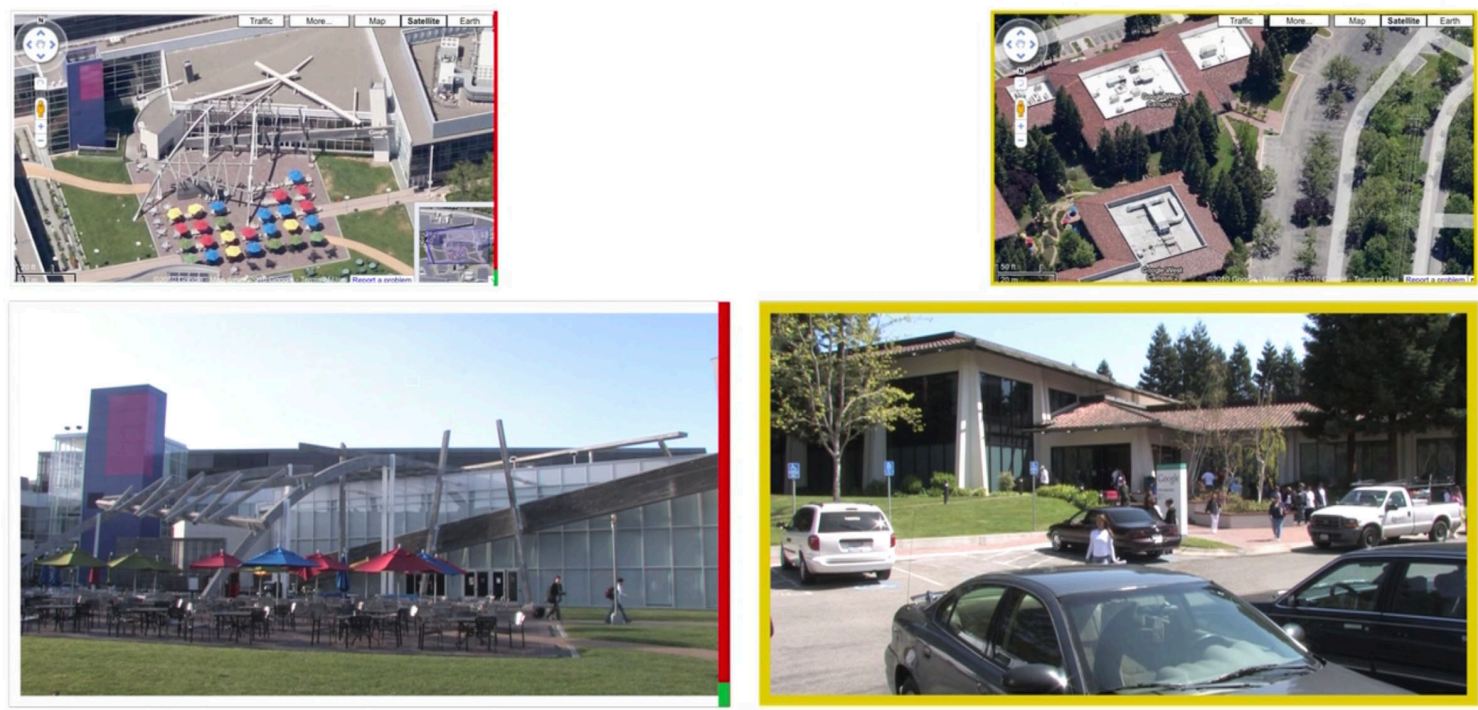

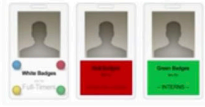

Figure 4. Andrew Norman Wilson, Workers Leaving the Googleplex, 2011. Screenshot from video. (C) 2019 Andrew Norman Wilson. Courtesy of the artist.

An earlier project by Wilson was inspired by best-selling literature on entrepreneurship, such as Tim Ferriss's 2007 book The 4-Hour Workweek: Escape 9-5, Live Anywhere, and Join the New Rich, which encourages its readers to outsource tedious administrative tasks through virtual assistant services. For Virtual Assistance (2009-11), Wilson subscribed to one such company, GetFriday, and initiated a "collaboration" with Akhil, the Bangalore-based employee he was assigned. Described by Wilson as a "research-based art project,"18 it posed the question, "If power is defined as the ability to manipulate resources across space and time, to what extent can power in my relationship with Akhil and GetFriday be re-distributed amongst a service where the normative use is one-way command?"19 Indeed, some of the tasks disrupted typical power dynamics by encouraging collaboration or allowing Akhil to make requests of Wilson in accordance with his own interests. One example involved asking Akhil to sit in his favorite spot in the office while jotting down his thoughts for 105 minutes while Wilson did the same. Another task took up Akhil's childhood hobby and an enduring interest in engineering by asking him to design a toy boat which Wilson then manufactured in the US and shipped to India for Akhil to set adrift in his hometown of Kerala (Figure 5). The action represented a sort of breakthrough for Wilson as it brought the "relationship outside of not only corporate space, but also corporate labor time, and into a personal, familial space." ${ }^{20}$ It also precipitated the snail-mailing of unique drawings by Akhil, which felt intimate compared to the rest of their communication required by contract to take place through the GetFriday chat function and under constant surveillance. ${ }^{21}$ 


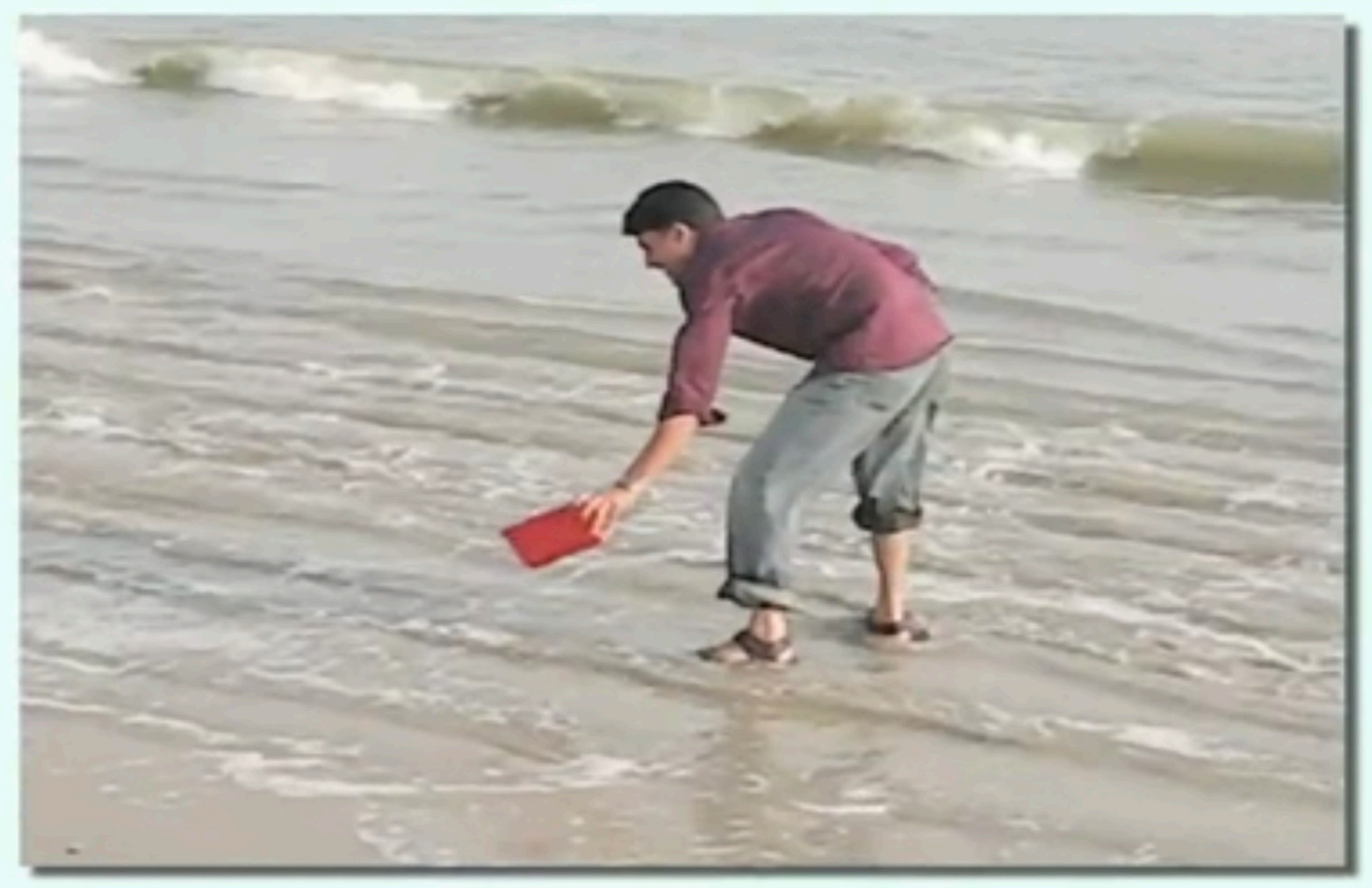

\section{Figure 5. Andrew Norman Wilson, Virtual Assistance PowerPoint, 2011. Screenshot from video. (C) 2019 Andrew Norman Wilson. Courtesy of the artist.}

In 2014, New York City-based artist Josh Kline produced a multimedia installation that took delivery workers as its subject. In describing his motivations, Kline explained, "Amazon was (and is) in the process of transforming our economy — making portraits of the people delivering their packages felt like a way to depict this transformation and its dehumanizing impact on workers. It was about the lower-paid jobs that replaced many of the jobs lost during the Great Recession."22 The installation featured 3-D printed sculpture, plastic bins filled with various materials including laboratory-grown bacteria, as well as video interviews with FedEx delivery workers or "helpers" recounting various aspects of the job (Figure 6). Unlike those hired directly by FedEx, who benefit from union representation, the workers featured in Kline's interviews were hired through contractors (Figure 7). Over the course of a series of questions posed by the artist off-camera, the two interviewees reveal their daily wages (between $\$ 80$ and $\$ 100$ for days sometimes lasting over twelve hours) and lack of benefits or paid time off, among other details including being held financially responsible for lost packages. When the subject of the first interview is asked whether his current wage is sustainable, he responds, "Your first instinct is, oh, I got a job. I'm going to make money, you know. I'm going to start providing for whoever you got to provide for. And then as the months go by, you start to realize that the money that you're making is not really enough." He goes on to explain that after sharing some of his wages with his mother and sister every month, as well as paying his share of the rent, he is often left with just $\$ 80$. "Out of those 
\$80, you've got to maintain yourself," admitting that he often skips breakfast and lunch, instead filling his stomach with coffee which the contractor provides for free. ${ }^{23}$

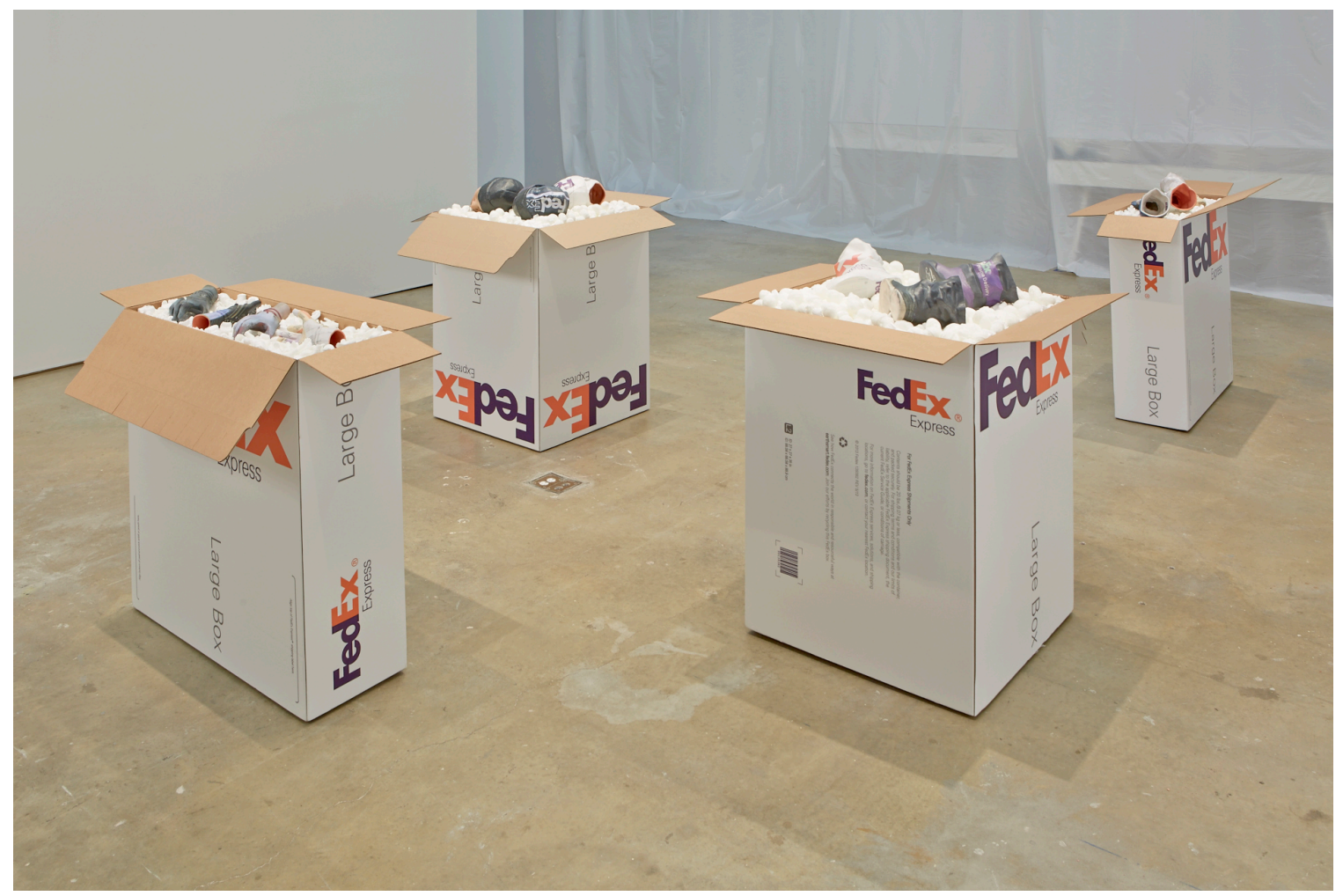

Figure 6. Installation View, Josh Kline: Living Wages/The Big Nothing, 2004, in ICA@50: Pleasing Artists and Publics Since 1963, Institute of Contemporary Art, University of Pennsylvania, June 25-July 6, 2014. (C) 2019 Josh Kline. Courtesy of the artist.

The 3-D printed sculpture, created using biometric scans, shows the worker's body disassembled, branded with the corporate logo, and placed in boxes cushioned by packing peanuts also in the shape of various body parts (Figure 8). It serves as a visual analogy for workers' disposability and interchangeability - simultaneously foregrounding the materiality of the physical labor they perform while evoking the looming threat of automation. As Kline explained, "The sculptures I made of these workers are about their objectification and dehumanization by the companies that employ them and by the people who they interact with while delivering packages." 24 Pushing this notion further, a third part of the installation features plastic bins containing nutrient gel and various objects mentioned during the interviews, including packing slips, instant ramen and a grape soda can. Also introduced into the bins are chromatically on-brand, purple and black genetically modified E. coli bacteria. ${ }^{25}$ Overall, the installation presents a multi-faceted portrait of the worker with an emphasis on the human — even biological — aspect of the labor being performed. According to the artist, the work involved "scanning them, and then printing out portraits in a variety of media and formats - mimicking the digitization of data via various 
avenues (credit cards, medical records, online shopping, banks, etc.) and the different 'portraits' that accumulate in their databases. ${ }^{26}$ As the convenience of online shopping and the expectation of near-instantaneous delivery adds a strain on those delivering packages, the work's hyperrealism reminds us of the physical exertion necessary to have a parcel show up at one's doorstep two days after the "complete order" button is clicked.

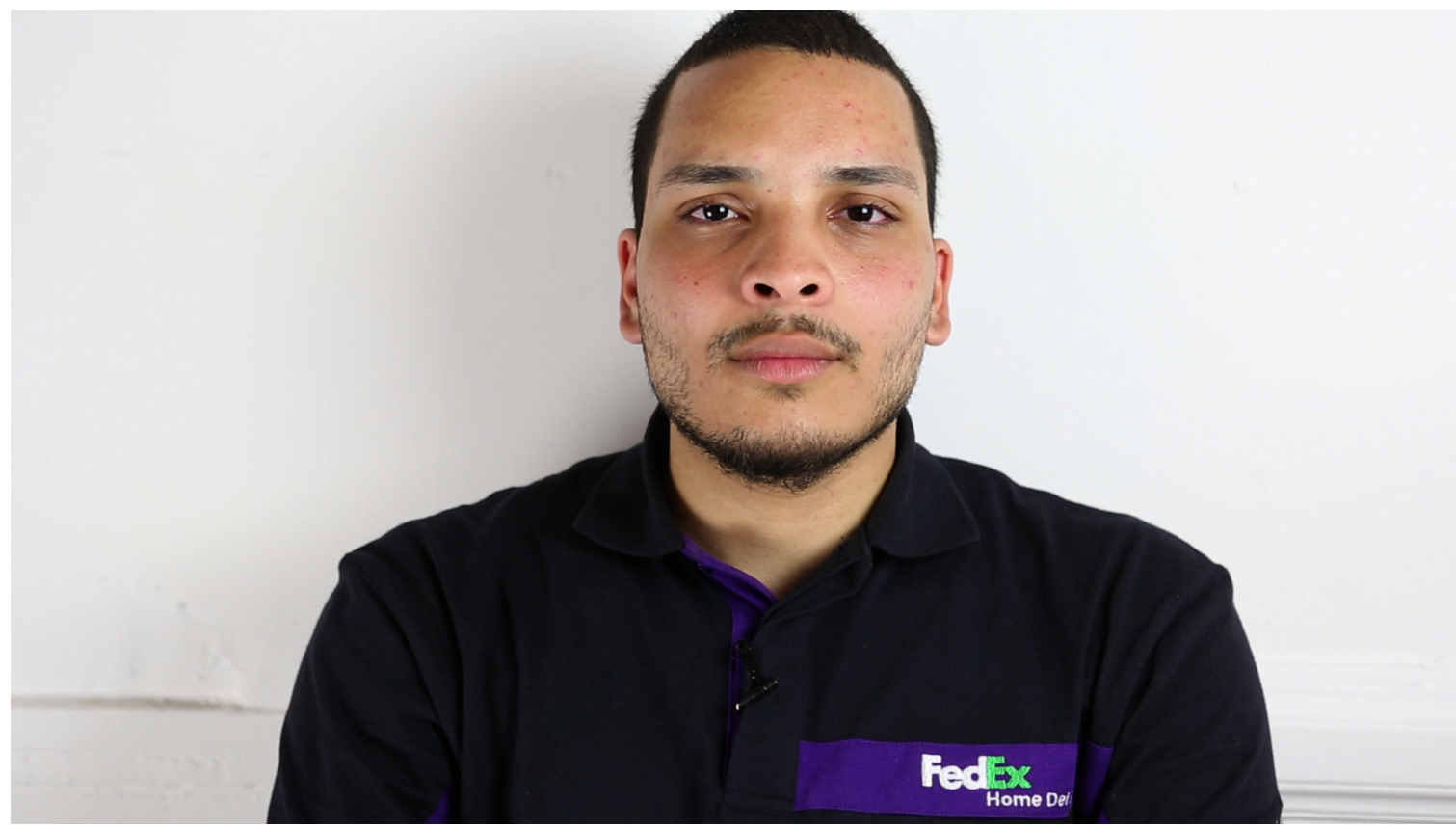

\section{Figure 7. Josh Kline, FedEx Delivery Worker Interview \#1, 2014. Screenshot from video. (C) 2019 Josh Kline. Courtesy of the artist.}

A 2016 video by Kline titled Universal Early Retirement (spots \#1 \& \#2) presents viewers with a future in which automation has alleviated or completely eradicated our workload (Figure 9). Functioning as "sincere" commercials for a Universal Basic Income (UBI), ${ }^{27}$ the two spots mimic political campaign ads in their uplifting tone, sentimentalism, and catchy tag line-_'It's about TIME." According to Kline, who collaborated on this project with an ad writer, "The video is a proposition about the possibilities of effective political communication." 28 The videos show people of all ages engaging in activities that bring them fulfillment and foster a sense of community - a young woman delivering food to an elderly neighbor, a man renovating his home, a mother helping her daughter with a science project - demonstrating just a few of the activities that an early retirement and steady income would allow. And like any effective advertisement, it encourages viewers to project their own desires onto the alternative reality being depicted on screen. Kline has offered, "If you're going to paint a vision of doom and devastation, I think it's also important to offer alternatives - some genuine hope devoid of cynicism.... We need to be able to imagine - to visualize — a better future in order to build one." 29 
While Kline's propagandistic project faces a steep hurdle in the face of entrenched American ideologies, such as the shame of unemployment and the myth of meritocracy, its visual representation of a possible future, using concrete and relatable examples, might contribute towards a potential solution. Recently, former 2020 Presidential hopeful Andrew Yang, who promised a "Freedom Dividend" of $\$ 1,000$ per month for every American adult over the age of $18,{ }^{30}$ brought the notion of UBI into the political mainstream. While UBI is not an alternative to capitalism, Kline argues for its potential utility: "It's a way of redistributing some of the wealth that's been stolen from workers over the last 40 years of neoliberal capitalism and also a way to mitigate the human impact of automation... [It is] also a way to slowly transition society towards a post-work paradigm." ${ }^{31}$ Considering increasingly urgent discussions around the need for a Universal Basic Income in response to the effects of automation and widening wealth inequality, Kline's video serves as part optimistic projection, part persuasive tool in the event this future becomes a reality.

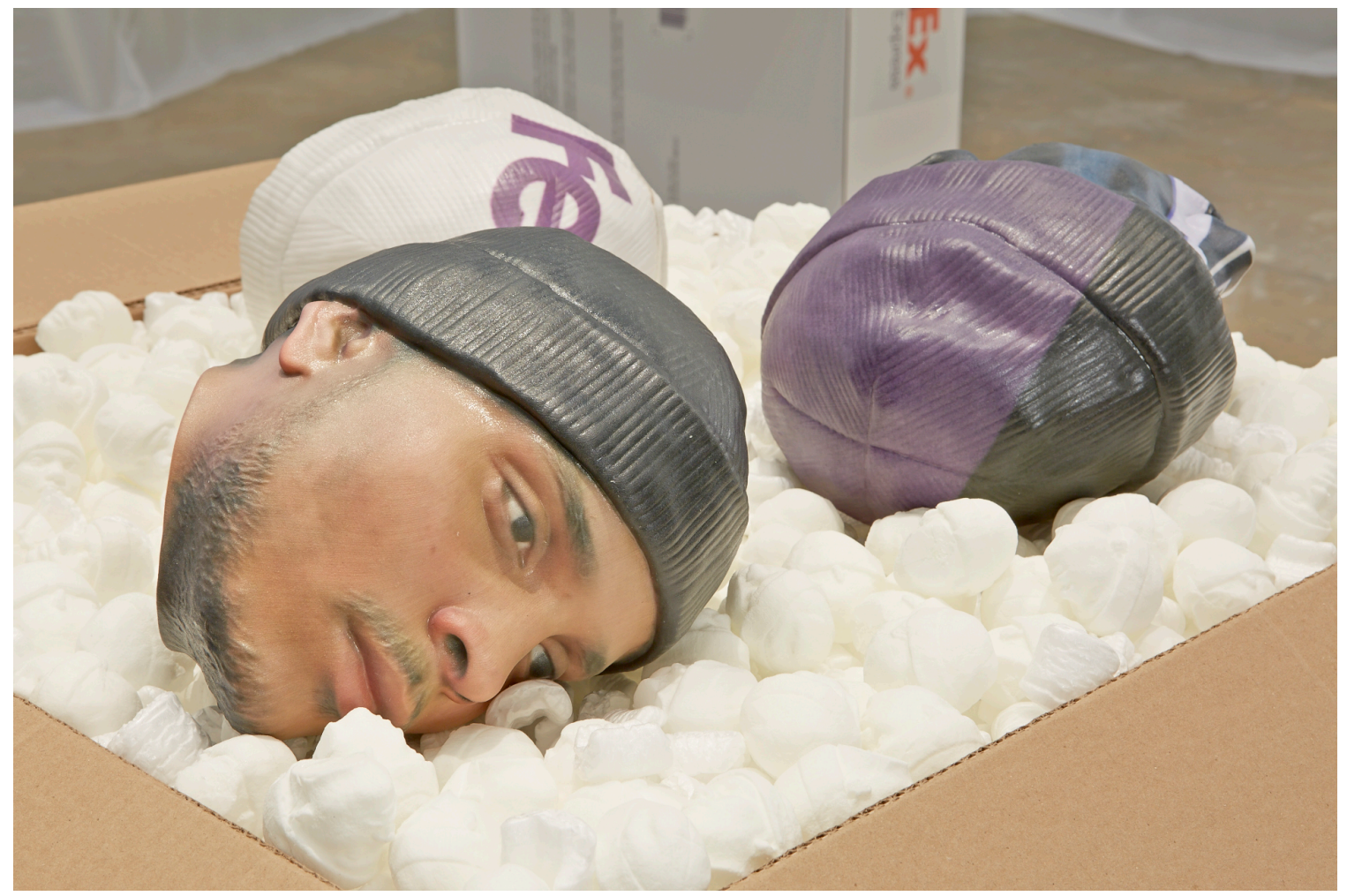

Figure 8. Josh Kline, Packing for Peanuts (Fedex Worker's Head with Knit Cap), 2014 (detail). Three 3D-printed sculptures in plaster with inkjet ink and cyanoacrylate, cast urethane foam packing peanuts, vinyl, cardboard, MDF. () 2019 Josh Kline. Courtesy of the artist. 


\section{THE UNIQUE POTENTIAL OF CONTEMPORARY VISUAL ART}

Considering the common revelatory function of the artworks outlined here, it is worth asking what sets these works apart from other forms of communication. In other words, what difference does it make to learn of Internet content moderation through video episodes on the Dark Net as opposed to through a New York Times article? Aside from their visual concretization of capitalist social relations, a key difference lies in the artists' (and by extension, the viewer's) implication in these relations through strategies of reenactment.

In Workers Leaving the Googleplex, Wilson captures the ScanOps employees on video as they collectively exit their building. The emerging crowd is juxtaposed with footage from other locations across the Google campus that show employees casually crossing the screen-often alone or in pairs - each headed in a different direction. When speaking about the work, the artist has explained that he was interested in documenting the movement of workers as evidence of the particularity of their labor. By structuring his video after the 1895 film Workers Leaving The Lumière Factory, Wilson explains that he "wasn't approaching [it] as an act of muckraking, but rather as an analysis of the transition from industrial labor to informational labor." ${ }^{, 2}$ While the mere act of filming these employees was threatening enough to prompt his immediate termination, the gesture can also be seen as a way of performing his role as an agent of the corporation by surveilling and monitoring its employees. Reading as multiple channels of security footage, with color borders that correspond to the number of employees in each categorized tier, the video generates a visual representation of an omniscient corporate POV.

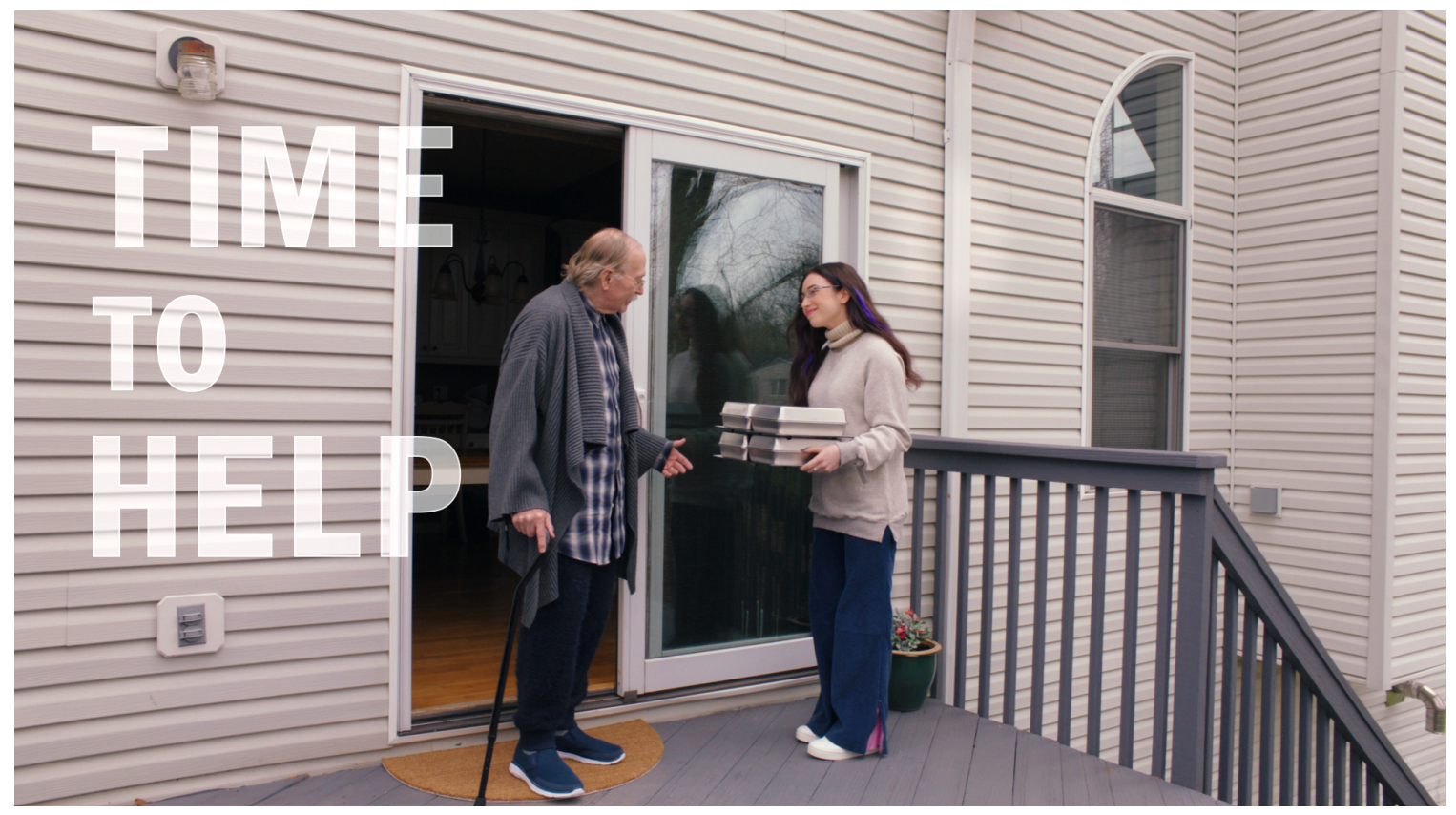

Figure 9. Josh Kline, Universal Early Retirement (spots \#1 \& \#2), 2016. 


\section{Screenshot from video. (C) 2019 Josh Kline. Courtesy of the artist.}

For Google, whose mission statement projects egalitarian values ("As technology continues to evolve, our commitment will always be the same: helping everyone find the information they need" ${ }^{\prime 3}$ ), the revelation regarding their unequal treatment of the ScanOps employees traveled far beyond the confines of the art world. Among the news sites that interviewed Wilson and wrote about his video, one Business Insider article seemed to justify the company's labor practices:

On the one hand, every big company will have workers who do repetitive tasks and who have less privileges. For example, employees at Amazon's warehouses have much strict [sic] working conditions than a computer engineer or a middle manager would, and it's intuitive why this makes sense. So there's nothing wrong with Google hiring a bunch of people (and probably not paying them a lot) and keeping them under tight rein to do repetitive tasks like scanning thousands of books every day. On the other hand, Wilson says that even janitors and security guards at the Googleplex are entitled to the awesome cafeterias and beanbag chairs, but the yellow badges aren't, and aren't even allowed to talk to anyone else. This seems weird, if nothing else. [emphasis added] ${ }^{34}$

In this example and others, Wilson's video reverberated beyond the confines of the white cube, exposing not only this instance of intentional obfuscation on the part of Google, but the pervasive justifications that uphold the capitalist system. In discussing the notion of the art world as an echo chamber, Wilson suggested that he often felt as if "these works inevitably and almost inherently just preach to a choir of people who are pre-loaded with the perspective that the works seem to want to communicate. ${ }^{35} \mathrm{He}$ continued, "I just had a lot of questions after making these projects and going around and talking to people. I actually feel really distant from the people that this work is about and closer to these people who agree with me but aren't actually doing anything."36 While Wilson certainly possessed a level of privilege in relation to the ScanOps workers (in the voiceover he explains that he had already planned to quit two months after his termination in order to attend graduate school), he also functions as a stand-in for viewers, who-although perhaps perturbed by his revelation —-will likely still use Gmail to share the video link with friends.

Kline also performs the role of the corporation, in this case FedEx, through his precise measurement, disassembly, and reproduction of the delivery worker. There is an implicit violence in the dismemberment of the worker's body, as well as in the fusing of limbs with digital instruments as if they constituted an extension of the flesh. Kline not only enacts the same instrumentalization as the employer, but also, through his sculptural reproduction of the employee, creates an art object which can be and has been bought and sold. The worker then is subject to a double commodification, first in his waged contract labor for FedEx and second by the art market that allows for collectors to count the 3-D printed body parts and video testimony among their holdings. In Virtual Assistance, Wilson takes this a step further by literally 
employing Akhil in an attempt to disrupt and reverse the usual flow of power. The FAQ slide towards the end of Wilson's Virtual Assistance PowerPoint (2011) succinctly outlines the project's ethical questions and ambiguous conclusions: "Does this project make you uncomfortable? YES. Is this discomfort a big part of why this project is interesting to you? YES." It then addresses the complicated question of personal gain: "In some ways were you getting more out of this relationship than Akhil? YES. In some ways was Akhil getting more out of this relationship than you? YES." The work therefore offers up the complex and messy aspects of their economic and personal relationship as a microcosm of larger systemic issues for the viewer's ultimate assessment.

While Eva and Franco Mattes disguised themselves as a company in order to hire content moderators for the interviews that form the basis of Dark Content, it is their role in BEFNOED that clearly demonstrates how their role as employers highlights the ethically problematic nature of wage labor relations. In contrast to the avatars in Dark Content, those who appear in the $B E F N O E D$ videos are not anonymized and yet have no control over the circulation of their own image with its potential to spread virally. Regarding the participants, the artists claim to "not know who they are, where they are, or even their motivations," and yet it is the motivation on the part of the artists that bears consideration. While some of their more innocuous instructions include covering one's hair with stickers, others such as licking a car rim seem unequivocally demeaning. As their intentions remained opaque to the workers, those willing to receive payment in return for performing these actions might have assumed nefarious motivations on the part of the employer. And are the artists' motivations in fact entirely benign? Much of their work tests ethical limits. While Dark Content draws attention to the psychological impact of disturbing imagery, other works by the artists either simulate such content - in the case of the previouslymentioned No Fun —or appropriate truly graphic imagery. ${ }^{37}$ Beyond the ethical question of trafficking in gruesome material, the work also complicates the relationship between the artist and the viewer, who is exposed to the same psychologically-taxing content.

All of the examples discussed here enact and problematize a set of social relations through the artists' performance as capitalist, whether literally or conceptually. These ethical ambiguities do not discredit their works as empty gestures, however, but function self-reflexively as symptoms of the relations that they depict. As Wilson has explained in reference to these earlier projects, "The hope was that the work was actually productive, in the sense that it didn't necessarily represent social processes, so much as it participated actively in these processes, and even helped constitute them.. ${ }^{38}$ By not only depicting forms of labor, but participating in relations of exploitation, these works concretize social dynamics that, under capitalism, are obscured or rendered invisible. 


\section{REGARDING ARTISTS' LABOR}

The effectiveness of these case studies and their very feasibility stems from an evolution in the nature of visual art practice, specifically developments typical since the 1960s, including delegated fabrication, appropriation, and a post-object emphasis on concept, followed by the rise of new media, video, and multimedia installation art. These individual developments are not new, but recent forms of artistic practice-research-driven and interdisciplinary-provide an opportunity for novel ways of reflecting on aspects of our society that are often overlooked or difficult to grasp. While these case studies are unified in their revelation and representation of obscured forms of labor, it is worth articulating what artistic labor itself looks like in these instances.

Apart from their form, content, and method of circulation, the works also share certain information-gathering strategies, including in-depth research and interviews with subjects. This approach parallels the reliance on interviewing in fields such as journalism, sociology, and anthropology, allowing viewers to grasp the factual basis of the work directly from its subject - in their own words and through their recounting of personal experiences. In this way, the viewers are brought into the research process, privy to the (albeit edited) transcript, allowed to draw their own conclusions. As Kline said of his interviewees, "The interviews felt like a way to present them as full human beings with intact voices, alongside these admittedly very brutal works that seek to embody their transformation into a product and service." 39

Some of the artists explicitly acknowledge the correspondences between the work they do and related disciplines. In Virtual Assistance, Wilson expressed hope that someone would take up the data he produced through his "collaboration" with Akhil to conduct further research into outsourcing - going so far as to provide a folder of primary source materials on his website. As he explained, "I'm no anthropologist, but my hope is that my day-to-day use of the 'field' can contribute to new categories of analysis. Though I may not be up for the task, I hope that someone more experienced will take on the project as a subject and tool for sociological analysis." 40 And, in fact, much of what these artists disclosed through their research is echoed in publications such as Ghost Work. Yet, due to their status as artworks, while producing knowledge, the artists who created them are not held to the strict standards of these parallel fields. The information need not necessarily be truthful or objective, and the artists' output is not peerreviewed or fact-checked. It remains up to the viewer to accept its validity and determine its value.

Without discrediting their efforts, one can acknowledge that this provides artists with a remarkable level of freedom. Wilson, who studied public communications and journalism, claims he "decided to become an artist because I felt like I could choose the matters I wanted to engage with." ${ }^{41}$ Crucially, the work of visual art practice evolves differently from that of other fieldsoften through MFA programs, studio time, grants, residencies, and exhibitions. The project-based 
nature of this work, while encouraging economic precarity, also allows artists to explore different topics while taking advantage of various and novel resources. Kline's plastic container petri dishes, for instance, were developed in collaboration with microbiologists from the University of Pennsylvania for his project Living Wages at the Institute of Contemporary Art in Philadelphia. Artists are often provided opportunities to collaborate with experts in other fields, producing work that adopts certain techniques and processes (e.g. growing bacteria in a laboratory) to remarkably different ends. The conflation of expertise and resources with an amateur's perspective and an artist's license for provocation is what can make these collaborations so generative. Contemporary visual artists are allowed to experiment across media and subject matter without being confined to strict categorization. As a result, the term "visual artist' varies wildly across individual practices.

Despite the output from academics and other knowledge workers, artistic practice holds a unique place in cultural production. This is due in part to expectations placed on contemporary art - to be provocative, subjective, ambiguous, challenging, contradictory, and abstract. It also receives certain allowances with regard to objectivity, profitability, finality, and legibility. It is, of course, also worth emphasizing that this method of artistic practice-open-ended, non-expert and interdisciplinary - involves a level of privilege and mediation on the part of the artists. Despite this, it functions as an important arena of cultural production when we consider it within the overall landscape of labor in the United States. While paralleling didactic media, the artworks discussed here go beyond their informational function. They reflect the system back to viewers, warts and all.

For the reasons outlined above, the work of art presents a generative medium for the representation of these social relations. First, its privileging of the visual allows for the concretization of what might otherwise be illusory and opaque conditions. Second, its circulation in galleries provides moments for focused reflection, while its accessibility on the Internet allows for its wide distribution. Lastly and perhaps most crucially, the artwork can offer up contradictions and ambiguities, letting these conditions lie bare and unresolved. The fact of complicity becomes not something to overcome, but an inherent and important part of the work.

\section{CONCLUSION}

Ultimately, the artworks discussed here are symptomatic. Any unease felt by the viewer can be attributed to an unease with the capitalist social relations that they reenact. Similarly, this article, while only scratching the surface, will hopefully serve as a provocation for further consideration of the role that contemporary visual art can play with regard to these issues. Admittedly, it raises more questions than it answers, just as the artworks glaringly highlight problems without necessarily offering solutions. Yet, beyond an artwork's political effectiveness, and regardless of its topic, the making of the work itself remains a significant gesture. When one considers the variety of professions within the United States, from waged retail work to precarious task-based 
labor to tenured professorships, it is clear that most require a very specific outcome. Artistic labor as discussed in this article is by contrast not constrained by as many parameters regarding its result.

In a 2016 article for e-flux, titled "The Artist Leaving the Googleplex," Wilson concludes by saying:

"I've been trying to articulate what I want out of art since dropping the varied endgames of 21 st century social realism.... But I keep waking up with the feeling that there's something to that uselessness. Not a point really - more like a knot. If being a person means being paranoid that you might be a puppet of some other force, like economic networks or algorithms or genetic coding, then being an artist means making things that defy that paranoia. It's not that there's no reason; ideally art takes a step beyond reason, towards what ought to be. To create disturbances in the seemingly natural order of things and unwind our counterfeit intuitions." ${ }^{42}$

While currently confined to a small group of artists, there is a necessity for open-ended cultural production that makes space for critical exploration without ethical resolution. When asked about the privileged status of art-making, Kline offered, "Making art is an intrinsic part of being human. The fact that so many people around the world do not make art is a testament to the dehumanization inherent in hierarchical societies based on real or artificial resource-scarcity."43 With their emphasis on the materiality of human labor entangled in digital technologies, these case studies offer a counterpoint to the shiny, opaque, and anonymous surfaces of the devices that their labor enables. They remind the viewer that in a system striving for seamlessness, there are those who will slip through the cracks.

\section{ENDNOTES}

1. Karl Marx, Capital: A Critique of Political Economy, Volume One, (London: Penguin Classics, 1990), 163.

2. Marx, Capital, 164-65.

3. Mary L. Gray and Siddharth Suri, Ghost Work: How to Stop Silicon Valley from Building a New Global Underclass, (Boston: Houghton Mifflin Harcourt, 2019), xvii.

4. Gray and Suri, Ghost Work, xxii.

5. For an introduction to the issues surrounding digital labor, see Christian Fuchs, Digital Labour and Karl Marx (New York: Routledge, 2014). In it, Fuchs provides a survey of the relevant literature by scholars including Mark Andrejevic, Nick Dyer-Witheford, Ursula Huws, Vincent Mosco, Andrew Ross, Trebor Scholz, and Tiziana Terranova, while using various case studies to 
explore the topic's wide breadth-from "slave work in ICT-related mineral extraction" to the "Google labour aristocracy."

6. Daniel Wenger, "Watch an Art Work About the Dark Web, on the Dark Web," The New Yorker, June 11, 2016, accessed July 3, 2019.

https://www.newyorker.com/culture/culture-desk/watch-an-art-work-about-the-dark-web-on-the$\underline{\text { dark-web }}$

7. Eva and Franco Mattes, Dark Content (2015), Artist Website, accessed July 4, 2019.

http://0100101110101101.org/dark-content/

8. Wenger, "Art Work About the Dark Web."

9. Ibid.

10. Mattes, Dark Content, Episode 4: “A darker place mentally,” accessed July 4, 2019.

http://5cqzpj5d6ljxqsj7.onion/ep.04.html

11. Mattes, "Dark Content, Episode 1: "I would prefer not to include my name" accessed July 4, 2019.

http://5cqzpj5d6ljxqsj7.onion/ep.01.html

12. Gray and Suri, Ghost Work, xxii.

13. Mattes, BEFNOED (2014-), Artist Website, accessed July 5, 2019.

http://0100101110101101.org/befnoed/

14. Christian Viveros-Faune, "Eva and Franco Mattes Dive into the Dark Web in New Tribeca Show," The Village Voice, May 28, 2014, accessed July 3, 2019.

https:/www.villagevoice.com/2014/05/28/eva-and-franco-mattes-dive-into-the-dark-web-in-newtribeca-show/

15. Andrew Norman Wilson, Workers Leaving the Googleplex, Vimeo, accessed July 10, 2019. https://vimeo.com/15852288

16. Ibid.

17. In a similar vein, Wilson's photo series ScanOps (2012-ongoing) features Google Books pages wherein the gloved hands of employees remain in view due to revelatory glitches in the system. The photographs conflate that which is literally manual with the intellectual labor that the books signify.

18. Hye Jean Chung and Athena Tan, "Virtual Assistance: An Interview with Andrew Norman Wilson," Media Fields Journal, no. 2 (2011), 3.

19. Andrew Norman Wilson, Virtual Assistance PowerPoint, Vimeo, accessed July 12, 2019.

https://vimeo.com/19006628

20. Andrew Norman Wilson, Toy Boat Task Overview, Vimeo, accessed July 12, 2019. https://vimeo.com/24405242

21. Wilson, interview with author, July 29, 2019.

22. Kline, email interview with author, July 26, 2019.

23. Josh Kline, FedEx Delivery Worker Interview \#1, 2014.

24. Kline, email interview with author, July 26, 2019.

25. Ibid.

26. Ibid. 
27. Kevin McGarry, "An Art Show That Addresses the Economic Collapse Head-On," The New York Times Style Magazine, May 6, 2016, accessed July 13, 2019.

https://www.nytimes.com/2016/05/06/t-magazine/art/josh-kline-unemployment-art.html

28. Kline, email interview with author, July 26, 2019.

29. Ginevra Bria, "Dissecting the Human-Machine System - A Josh Kline Interview," Widewalls, November 22, 2016, accessed July 15, 2019.

https://www.widewalls.ch/josh-kline-interview-ginevra-bria/

30 "The Freedom Divided," Yang 2020, accessed October 25, 2019.

https://www.yang2020.com/policies/the-freedom-dividend/

31. Kline, email interview with author, July 26, 2019.

32. Wilson, Workers Leaving the Googleplex.

33. "Our Mission," Google, accessed July 4, 2019.

https://www.google.com/search/howsearchworks/mission/

34. Pascal-Emmanuel Gobry, "At Google, Talking To Coworkers Can Get You Fired," Business Insider, April 30, 2011, accessed July 5, 2019.

https://www.businessinsider.com/at-google-talking-to-coworkers-can-get-you-fired-2011-4

35. Wilson, interview with author, July 29, 2019.

36. Ibid.

37. Wenger, "Art Work About the Dark Web." In 1998, Eva and Franco Mattes invented the persona of a Yugoslavian artist named Darko Maver who created hyperrealistic sculptures of mutilated corpses to highlight the violence in his home country. The artists eventually revealed that images of the supposed sculpture had been sourced from the shock site rotten.com and, therefore, may have depicted true gore and violence.

38. Jared Quinton, "Producing the Social: Andrew Norman Wilson Interviewed by Jared Quinton," BOMB Magazine, Feb 21, 2019, accessed July 11, 2019.

https://bombmagazine.org/articles/producing-the-social-andrew-norman-wilson-interviewed/

39. Kline, email interview with author, July 26, 2019.

40. Chung and Tan, "Virtual Assistance," 15.

41. The Photographers Gallery, "Free Lunch on Google: an Interview with Andrew Norman Wilson," The Photographers Blog, November 25, 2013, accessed July 10, 2019.

https://thephotographersgalleryblog.org.uk/2013/11/25/free-lunch-on-google-an-interview-withandrew-norman-wilson/

42. Andrew Norman Wilson, "The Artist Leaving the Googleplex, e-flux Journal, \#74, June 2016, accessed July 10, 2019.

https://www.e-flux.com/journal/74/59791/the-artist-leaving-the-googleplex/

43. Kline, email interview with author, July 26, 2019. 


\section{AUTHOR BIO}

Ana Torok is a curator and art historian based in New York City. She earned an MA in Art

History from the Courtauld Institute of Art in 2016. She is currently a Curatorial Assistant in the Department of Drawings and Prints at the Museum of Modern Art and previously worked in the curatorial departments of the Solomon R. Guggenheim Museum and the Whitney Museum of American Art, while organizing exhibitions independently. 